\title{
Documenting and Describing the Transcultural
}

\section{Qualitative Research in \\ Theological Communication}

Evan F. Kuehn, North Park University

Matthew Ryan Robinson, Rheinische Friedrich-Wilhelms-Universität Bonn Hadje C. Sadje, Evangelische Theologische Faculteit, Leuven

\begin{abstract}
Qualitative methodological approaches have become increasingly important for theological research as lived theology and ecclesiological practices are recognized as being a relevant part of the theological information ecosystem. These new approaches require attention to how field research in theology is documented and described. Evan Kuehn (North Park) will discuss the transculturality of theological research and the relevance of qualitative approaches to theological librarianship. Hadje Sadje (Leuven) will share about his research on the political theology latent in the practices of Oneness Pentecostal congregations in the Philippines and the role that documentation and description play in this research. Matthew Ryan Robinson (Bonn) will discuss the nature of non-textual theological artifacts by focusing on two case studies-a painting from Ethiopia and a devotional cross from the Philippinesas objects that present challenges and opportunities for extracting, coding, and analysis.
\end{abstract}

\section{TRANSCULTURAL QUALITATIVE RESEARCH AND THEOLOGICAL LIBRARIANSHIP}

Evan F. Kuehn

In this panel, we would like to introduce new theological research being done by ourselves and some of our colleagues in order to achieve three goals:

1) to introduce the concept of transculturality for theology,

2) to introduce the role of qualitative methods in theology, and 
3) to discuss the challenges and opportunities that transcultural, qualitative research poses for theological librarianship, specifically with regard to documenting and describing theological objects.

\section{Transculturality}

So, first: what do we mean by transculturality?

The concept of "culture" is bounded: one talks about American culture as something that excludes those who do not live here (and, in fact, often excludes many who do live here as well). The idea of German culture or Filipino culture likewise operates largely within nation-state boundaries and assumes some level of homogeneity and impenetrability.

In order to avoid these connotations as well as for other reasons, missiology faculties began in the 1970s to rename themselves as intercultural studies, in order to signal a shift in our understanding of human cultures to one that recognized globalizing forces and the important role of interaction between cultures.

Interculturality still often operates on an assumption of interaction between bounded wholes, though. We propose, therefore, that transculturality better describes the interpenetrations and shared reality of human social life in the midst of multiple belongings, migration, friendships, and the waxing and waning of political legitimacies.

If we understand theological communication as transcultural, then, how will this affect research methods?

\section{Qualitative and Empirical Methods}

A focus on the social and historical conditions of human faith is unavoidable for theologians today. Social scientific disciplines have long since changed our understanding of religious studies, but the hermeneutical and ecclesiastical functions of theology have tended to preserve a pre-critical methodological stance among theologians. This is true especially where more conservative religiosity dominates local culture and where whiteness and/or its colonial influences obscure the fact that all theology is contextual theology.

Qualitative and empirical methods signal a sea change in how theological research understands itself, and with these changes come new needs. Matthew Robinson (2020) points out the basic challenge of such approaches in his introduction to the symposium "What Does 
Theology Do, Actually?” He writes: “there is just so much theological data in the world to be collected, documented, and represented, and very little of that total 'amount' ... can be found or even accessed in one research context or format."

Some of these changes will be more significant for the theologians themselves to grapple with rather than for the theological librarian. Many of us, or at least our colleagues in the archives, already collect and describe oral histories, non-monographic literature like pamphlets, and non-text objects. In these cases, it can be helpful for subject liaisons to introduce these objects as relevant not only for the church historian but also for the systematic theologian.

But theological objects are less traditional still than some of these examples. Consider the following project: a systematic theologian wants to scrape tweets from October-November 2019 related to civil unrest in Addis Ababa, preferably from multiple languages, in order to disambiguate ethnic from religious violence and to analyze how the concept of "neighbor" is deployed in these contexts. How are a seminary library's infrastructure and tools equipped to assist in this research? There is very little in the way of description that maps these new digital objects onto an existing research literature, and most likely the ephemeral nature of digital communication means that the objects studied in such a project will not be incorporated into the research literature in any substantial way.

This is fine, to a certain extent. Libraries are not merely data repositories, and the challenges of interdisciplinary field work are not always the librarian's job. At the very least, however, such projects will require metadata that avoids importing Eurocentric organizational biases to multilingual and trans-ethnic conceptual contexts, compatibility with the most relevant social media platforms, and a scholarly communications infrastructure that isn't just open access in the sense of lacking a paywall, but is also attentive to how theology functions within Ethiopian seminaries, both accredited and unofficial, so that OA actually establishes access amidst political, technological, linguistic, and file format complexities. These are all problems that theologians will increasingly face in their research, and it is important that theologians and theological librarians have conversations about what infrastructure is required to make this research function smoothly.

In the next two short presentations, Matthew Robinson and Hadje Sadje will discuss their current work as it relates to transculturality 
and qualitative methods, in order to ask two questions: "What does theology do today?" and "How might this work be better integrated into the initiatives and workflows of Atla, its member institutions, or similar organizations committed to theological research?”

Dr. Matthew Robinson is research associate in practical theology at the University of Bonn, as well as a fellow in their Institute for Hermeneutics. Matthew and I have recently co-authored a book that sets 19th-20th century Protestant theology in conversation with Niklas Luhmann's social systems theory, and we are currently editing a two-volume handbook with Brill on empirical and qualitative methods in theology. Matthew's immense work on the transcultural functions of theology led to an international symposium in Bonn this past summer that Hadje, myself, and others took part in and which is the inspiration for today's panel.

Hadje Sadje is volunteer faculty at the School of Global Studies and Human Rights Studies, Foundation Academy of Amsterdam, the Netherlands. He has published numerous articles on religion and politics, especially focused on decolonial and liberation theologies, peace-building, and Filipino Oneness Pentecostalism.

\section{HOW A TRANSCULTURAL PERSPECTIVE MIGHT INFLUENCE THEOLOGICAL RESEARCH ON THEOLOGICAL INFORMATION AND ARTIFACTS}

Matthew Ryan Robinson

After colonial hegemony, and given the incredible diversity and distinctiveness of forms of theological communication around the world today, is theology condemned to parochial particularity? Is meaningful transcontextual theological work still possible? If by "theological work" we mean something like "globally recognized" claims about Christian belief and practice, then the answer seems to be clearly "no." However, description of general patterns in theological communication might be, for, as much particularity as there is, everyone is using Facebook or TikTok, and they are doing so to respond to shared concerns, such as the coronavirus pandemic or systemic racism and police brutality. At the same time, any theological analysis of global trends must still be able to recognize and take seriously local particularities. Thus, analysis of the functions of theological communications transculturally not only seems plausible but needed. 
1. The transcultural is something to be aware of in the ways we characterize research areas, information organization, and knowledge production. Why?

With exploration and industrialization, societies worldwide had begun the irreversible process of differentiation into functional systems which operated (and operate) irrespective of ethnolinguistic, religious, or national borders; trade, law, and natural scientific inquiry illustrate the point. And with functional differentiation, shared meaning among human beings increasingly forms and circulates along those global sightlines: international education standards, global transportation needs, human rights, and now the collective effervescence of social media communities-all of these illustrate a certain kind of transcendence of cultural particularity.

On the other hand, this does not mean that human beings no longer develop what anthropologist Clifford Geertz called "patterns of meanings embodied in symbols," which symbols, with time, become embodied in repeated performances and repeatedly engaged artifacts. Culture, evolve as it may, develops over very long periods of time and in complex, durable forms that do not change drastically from one day to the next.

The "transcultural" thus attempts to analyze two things:

a) globe-spanning forces, with attention to the ways they create multiple, and overlapping intersections at the site of individual and communal lives; and

b) how local "patterns of meanings" persist and evolve interrupting these intersections and even exerting counterinfluences.

The study of theology at the site of intersecting transcultural pressures and cultural obduracy requires not only intercultural contextualizations but attention to transcultural complexity.

2. To study theological engagements with the transcultural will require research methods and knowledge production and organization orientations capable of recognizing, documenting, and interpreting non-traditional theological knowledge forms.

There are more than two billion Christians in the world and, as Gustavo Gutierrez $(1988,3)$ famously wrote, "there is present ... in every Christian community a rough outline of a theology ... mani- 
fested in life, action and concrete attitude." Only a small number of the world's Christians do their theology in seminar rooms, at conferences, and in monographs. This means there is a lot of theology out there that is not even on the radar of academic theological research. How, then, are we to identify the forms theologies are taking and what they are doing in the encounter with transcultural pressures? One option is for theology to follow the material turn.

Figure 1 is a pictorial narration of the Kebre Negast-the founding myth of Solomonic divine-right kingship that supported Ethiopian kings and emperors from at least the fall of the Zagwe dynasty in 1270 until the overthrow of Haile Selassie in 1974. It tells the story of the Queen of Sheba and her visit to Jerusalem to meet King Solomon. She bore a son to Solomon, and Solomon recognized this son, Menelik I, as his rightful heir. The Israelite Ark of the Covenant was spirited with Menelik back to Ethiopia, thereby theologically conferring divine election onto Ethiopian rulers, the Ethiopian Orthodox Church, and, by extension, all of Ethiopia. Copies of this picture can be found displayed prominently in the halls of Addis Ababa University as well as being available for purchase in any little shop selling gifts or religious items. In both its material presentations and imagined but embodied daily re-performances of Ethiopianness (Ityopiawinnet), it is doing theology all of the time.

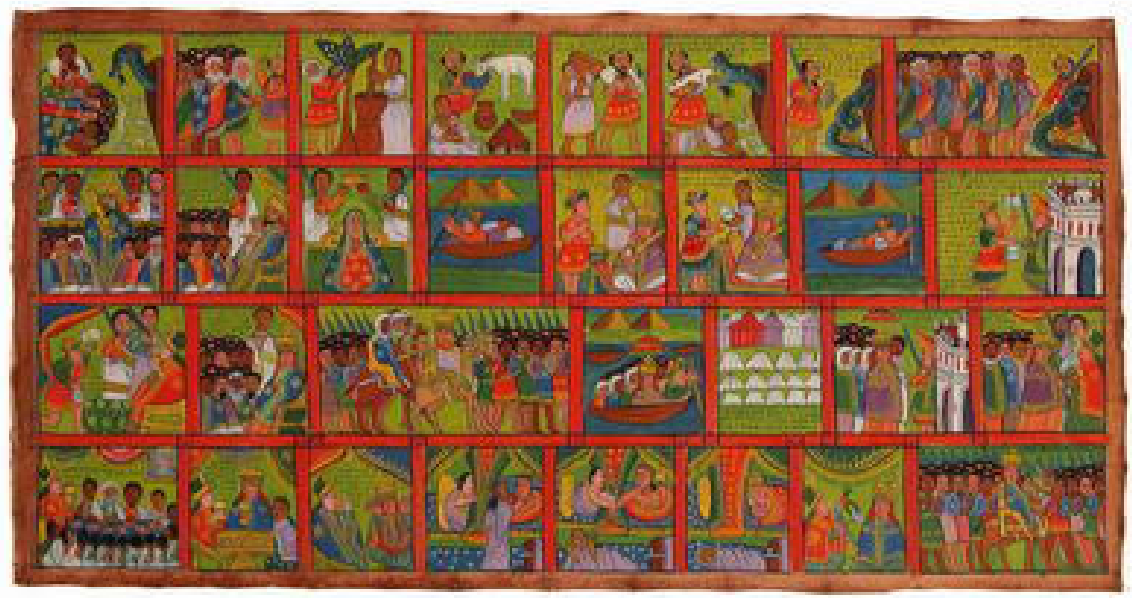

FIGURE 1: Depiction of the Kebra Negast (commons.wikimedia.org/wiki/File:Saba_ ephiop.jpg). 
Figure 2 is a picture of the Hesus Nazareno, the Black Nazarene, which is translated every year on January 9 from the old walled city to the Minor Basilica in Manila in a procession that attracts $>200,000$ and can last up to 20 hours. The legends surrounding the Black Nazarene are as composite as the material object itself. Parts of the physical object originate in 17th-century Mexico, while replica replacement pieces were fashioned in the Philippines in the 1990s, but the questionability of the object's provenance and integrity leave no room for doubt among the faithful as to the excessive efficacy of

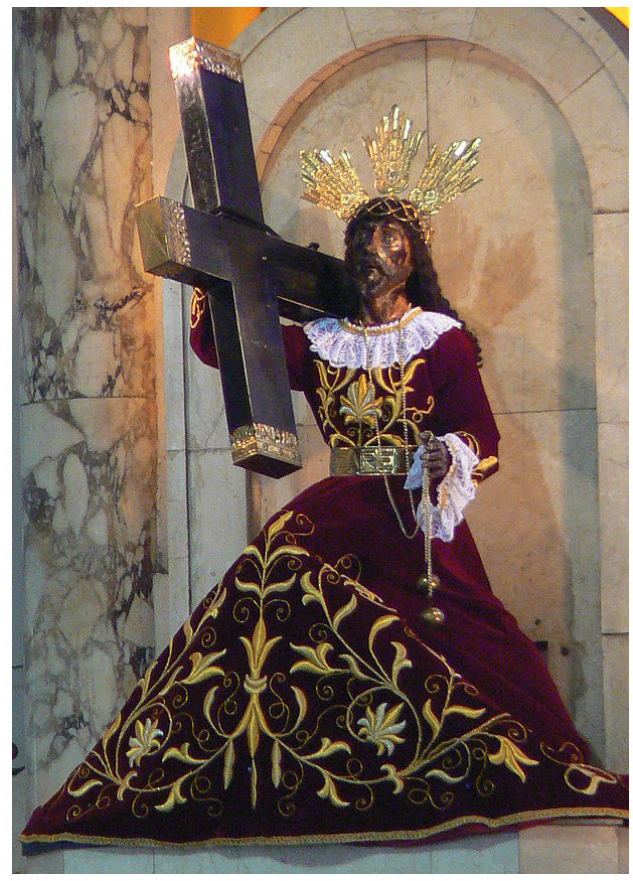

FIGURE 2: Hesus Nazareno (en.wikipedia. org/wiki/Black_Nazarene\#/media/ File:Black_Nazarene.jpg). its healing powers. Like the Kebre Negast, the Black Nazarene might be regarded as a theological artifact-an object doing theology on a massive scale. They exemplify the ways that the work of calibrating the world as it should be with the world as it is forms in lived encounters and re-presentations that do not, for reason of their being embodied and materially interactive, fail to possess highly nuanced theo-logics.

While more sensory and material forms of religious cult are common in Catholic and Eastern and Oriental Orthodox piety, the same may be said of much of contemporary Protestant, especially Pentecostal, piety. For many Pentecostals around the world, objects such as prayer cloths and anointing oil perform vital mediations conferring divine blessing on the everyday. The definition of materiality can be fruitfully extended to include the vast collection of CDs and DVDs, films, popular music, and social media presences such as YouTube channels or Twitter accounts, public statements, and advertising or educational materials. As Alfred Gell (1992) has 
argued concerning the agency of artworks, symbolic forms and spaces exhibit a remarkable capacity "for securing the acquiescence of individuals in the network of intentionalities in which they are enmeshed.”

3. But how would we identify data as "theology-relevant," organize theological information, and produce theological knowledge?

Basically, I want to take the data lifecycle as a model for theological research. I want to collect theological artifacts, code them so that they are cross-searchable, and curate them in ways that create information triples that then, eventually, organically start to reveal new relationships and thereby indicate recent and ongoing developments in theological self-understanding. A partnership of theology, information science, and sociology. But how would the coding work? How can objects, practices, scenes and settings, spaces be tagged and be categorized? On the one hand, there is the risk of importing and reproducing-whether consciously or unconsciously-the epistemologies of the powerful (of those who are in the position of power and having the authority to decide what counts as a meaningful tag). On the other hand, it seems like manual categorization is unavoidable. We are not talking about data sets that are big enough to apply machine-learning algorithms to them. Even those require manual organization of terms and training. Would it make sense to start with a basic lexicon of terms built from a generic systematic theology? Or perhaps, even more basic, the terminology of one or more creeds? And then, how would the lexical terms be applied to specific instances? Self-ascription? Or perhaps a multi-step process in which the researcher collects things $\mathrm{s} /$ he identifies as significant, codes them, and then seeks "verification" from participants with insider relationships to the field in question? And how could the lexicon be expanded, which, I take it, would be desirable in order to capture new relationships?

The research field is theology engaging transcultural pressures, the methods for this will be increasingly qualitative and information-science oriented, and for that new partnerships with embedded librarians and with data scientists are needed. 


\section{THE CASE OF FILIPINO PENTECOSTALISM}

Hadje C. Sadje

\section{Pentecostalism in the Philippines}

Terence Chong, senior fellow and regional editor of the Yusok Ishak Institute-Institute of Southeast Asian Studies, argues that Southeast Asian Pentecostalism, specifically in Malaysia, Indonesia, the Philippines, and Singapore, are simultaneously recognizable as part of a global phenomenon of Pentecostalism. In 2006, according to the Pew Review Center report, the Philippines is one of the top Asian countries that has growing Pentecostal and charismatic movements. Likewise, a well-known British Pentecostal scholar-Allan Anderson-strongly believes that the Pentecostalism and charismatic movements are the most popular and fastest-growing social force in the Philippines.

Today, under the presidency of Rodrigo Duterte, the excessive public mingling of religion and politics is perceptible. It seems that to know Duterte's populism is to understand his religious views. According to Jayeel Cornelio and Erron Medina (2018), "To appeal to patriotism is a religious conviction because it invokes a vague but transcendent entity-the Filipino people." They further argue, "We thus argue that reflecting on Duterte's enduring popularity needs to recognize that supporting his leadership is not just a political choice. It is also religious.”

During his 2016 campaign for the presidency, religious movements emerged as a major player in Duterte's rise to power. For instance, one of the staunch supporters of President Duterte is Apollo C. Quiboloy, who is a popular Filipino Oneness Pentecostal preacher and a self-proclaimed "Son of God." Quiboloy has openly supported Duterte's presidency. In fact, Quiboloy publicly claimed that God wanted Duterte to be a president. Looking at the classical Pentecostal perspective, Quiboloy's political endorsement as a preacher is not common Filipino Oneness Pentecostal political behavior. Although political endorsement is common among the largest Trinitarian Christian communities, including the Roman Catholic Church, classical Filipino Oneness Pentecostals have avoided direct political engagements, with the exception of two Oneness Pentecostal movements: the Kingdom of Jesus Christ the Name Above Every Name and the Jesus Miracle Crusade Inter- 
national Ministry. Yet, despite the presence of these two Oneness Pentecostal movements in Philippine politics and mainstream media, Filipino Oneness Pentecostal is not well-studied. In his intensive research on Filipino Oneness Pentecostal movements, Johnny Loye King $(2016,2)$ writes, "This is just one example of how Oneness Pentecostalism has been overlooked in the Philippines, and possibly throughout the world.” Thus, many researchers, as King argues, if they are even aware of the movement's existence, believe that Oneness Pentecostalism is worthy of little more than a footnote.

Moreover, religious life in the Philippines is experiencing a recrudescence of Pentecostalism. Whereas many of the older historical denominations are suffering serious decline and membership losses, Filipino Oneness Pentecostals are enjoying an expansionist phase and buoyant growth. For example, according to the United Pentecostal Church Philippines, UPC Philippines have 2,500 local churches nationwide. Quiboloy, as an executive pastor of the Kingdom of Jesus Christ the Name above Every Name, claims to have four million followers; Jesus Miracle Crusade International Ministry claims to have 1,500,000 members in the Philippines and 15 other countries. However, Filipino Oneness Pentecostal groups vis-à-vis their faith and churches have been remained understudied in the Philippines. More often than not, Filipino Oneness Pentecostals are regarded as one of the major cults. As more and more sources become available, and as its advancing study continues to raise the interest of scholars and historians in the unique phenomenon of global Pentecostalism in the 21st century, Filipino Oneness Pentecostalism deserves and needs to be explored further.

First, as a forgotten shadow of global Pentecostalism, Filipino Oneness Pentecostals are relatively understudied in the Philippines. Second, oneness theology is one of the most misunderstood theological concepts of our time-often mistaken for cultic and certainly considered by many as a non-Christian teaching. Third, like many other Christian denominations, the fact that Oneness Pentecostals perceived eschatology as one of the central "Apostolic" teachings, to some extent, shapes their social behavior and public engagement. Lastly, the ongoing problems (poverty, human rights violations, natural disasters, corruption, etc.) that have beset the Philippines for many years revealed, according to Joseph Rommel L. Suico, the ambiguity of the Pentecostal movement's understanding of its role in society. In the same vein, Filipino Oneness Pentecostals seem oblivious to 
social issues. This suggest that the public engagement of the Filipino Oneness Pentecostals has not been adequately researched. Consequently, for outsiders, Filipino Oneness Pentecostals are susceptible to a lack of firm leadership, fanaticism, and highly emotional behavior.

\section{Research Gap}

There has been some work done on similar research to a Philippine context, but nothing has been researched on Oneness Pentecostal public theology. Some studies concentrated on Trinitarian Pentecostal and charismatic movements, and no study has been embarked on public theology of the Oneness Pentecostal movement in the Philippines. Thus, this research seeks to investigate the political theology latent in the practices of Oneness Pentecostal congregations in the Philippines and the role that documentation and description play in this research.

\section{Methodology}

The study is a critical evaluation of the public engagement of Filipino Pentecostalism. With the aid of grounded theory, ethnography, and decolonial methodology, material was gathered and analysed from a case study of Filipino Pentecostal movements-specifically, the Jesus Miracle Crusade International Ministry and the Kingdom of Jesus Christ the Name Above Every Name, utilizing qualitative methods (documenting and describing theological objects), participant observation, literature analysis, life-story interviews, preaching/sermons, testimonies, articles of faith, church programs, Sunday school materials, visions and missions, civic engagements, etc.

\section{WORKS CITED}

Cornelio, Jayeel and Erron Medina. 2018. "Duterte's Enduring Popularity Is Not Just a Political Choice-It Is Also Religious.” New Mandala, September 3, 2018. www.newmandala.org/dutertesenduring-popularity-not-just-political-choice-also-religious.

Gell, Alfred. 1992. "The Technology of Enchantment and the Enchantment of Technology." In Anthropology, Art, and Aesthetics, edited by Jeremy Coote and Anthony Shelton. Oxford: Clarendon Press. 
-1998. Art and Agency: An Anthropological Theory. Oxford: Oxford University Press.

Gutierrez, Gustavo. 1988 [1971]. A Theology of Liberation. Maryknoll: Orbis Books.

King, Johnny Loye. 2016. "Spirit and Schism: A History of Oneness Pentecostalism in the Philippines.” PhD diss. University of Birmingham.

Robinson, Matthew. 2020. “'What Does Theology Do?' as a Transcultural Research Perspective: A 'Model of' a 'Model for' Theological Research.” In What Does Theology Do, Actually? Observing Theology and the Transcultural, 19-43. Leipzig: Evangelische Verlagsanstalt $\mathrm{GmBH}$. 